\title{
報 告慢性関節リウマチの保存的治療
}

\author{
岡 崎 健 ${ }^{*}$
}

要旨 昭和 59 年の大田区報によると, 大田区に住む 40 歳以上の男女の 調査で7\%がいわゆるリウマチ性疾患に罹っている。従って，これら リウマチ性疾患の1/10に過ぎない慢性関節リウマチ(RA)の正確な診断が, ある治療法の効果を評価する際，最も重要である。

私の経験では，最新の抗リウマチ剂を含む大部分の治療は RAの関 節破壊の自然経過を変えられないと思われ，我々はRA患者の管理し か手段がないと認めざるを得ない。

$\mathrm{RA} の$ 保存的療法は，抗炎症剂の効果的な投与だけでなく，四肢変 形や拘縮の予防も必要とする。

RA 患者の各関節について，変形や拘縮を防ぐためのリハビリテー ションプログラムを示した。疼痛の精神的軽減法は, 東洋医学では効 果的に使われているが，RAの基本的な管理法を忘れてはならない。

1963年，アメリカリウマチ協会の発表した骨関 節や結合織に病変を示すいわゆるリウマチ性疾患 は, 大項目で13に分類され, 病名としては 100 近 くもある。従って, 温泉の効能書に書いてあるよ うなリウマチとは，これら結合織に症状を示す広 い意味でのリウマチであり，今日話題にする慢性 関節リウマチ(以下 R A ) はこのごく一部に過ぎな い。

ちなみに, 昭和 59 年大田区の 40 歳以上の男女 1,200 名のアンケート調査で, 腰痛・神経痛・五十肩な どの疼痛性疾患を含むリウマチ性疾患は $7 \%$ にも 及び，RAを全人口の $0.5 \%, 40$ 歳以上ではもう少 し多いとしても，この約10倍ものいわゆるリウマ チで患者が悩んでいることになる。一般的にリウ マチを治療するということは，必ずしも RA を治 療することでなく，RAの診断そのものが先ず問 題になる。とくに RAの初期は，専門家でも変形

*Ken OKAZAKI 七沢リハビリテーション病院

Key Words : 慢性関節リウマチ, 自然経過, 保存的治療, 疼痛对策, リハビリテーション
性関節症や他の膠原病，単なる腱鞘炎や五十肩な どと区別出来ない場合がある。

また確実に RA と診断された場合でも，RAに は多くの型があり，2〜3 年で急速に進行するも のから，数十年たっても一部の関節のわずかな破 壊や強直にとどまるものまでいろいろあり，関節 の炎症・疼痛も次々と移動し, 朝と晚, 日, 月, 年単位, 季節によって変化し, 治療しても悪くな ったり，何もしなくても自然に炎症が治まったり する気まぐれ病なので，自然経過の複雑さを知ら ずにRAを治したなどとおこがましいことを言っ てはならない。私の30年の RA 治療の経験では, 現在あるすべての治療法は関節の破壊にほとんど 影響せず，炎症や疼痛が一時期治まっても，一部 の関節の破壊は勝手に進行したり，進行が止った クしている。従って, 我々の行っている治療はRA を治しているのではなく，管理しているに過ぎな いと思うべきである。しかし，管理しないとどう なるかを考えてみると，次に示すような変形・拘 縮・強直が進行し, 疼痛にも恼まされて日常生活 動作がどんどん低下していくことになる。ここに 
$\mathrm{RA}$ 治療の意義が存在するのである。

RAの治療には内科的治療, 整形外科的治療, リハビリテーションの3つがあって，お互に話し 合いながら行われるべきであるが，現在日本では， 三者が独立して別々に患者を診療し，協力がほと んどなされていない。私の話は，このうち内科的 治療とリハビリテーションについてであり，保存 的にはどうやって，どこまで治療が可能かがわか っていただければ幸いである。

初期の RA は遠位指関節の腫脹するへバーデン 結節，膝に関節液がたまる変形性膝関節炎，腱鞘 炎，五十肩，痛風などと鑑別することが大切であ るが，末期の，RA では次に示すような特有の変形, 拘縮がおこるので，診断は簡単である。

手指の変形として, 近位指関節が過伸展し遠位 指関節が屈曲するスワンネック変形は，放置する と物がつまめなくなる。逆に，近位指関節が屈曲 し，遠位指関節が過伸展する変形はボタン穴変形 である。中手指関節で指骨が尺側に曲る尺側偏位， 指の関節がとけてブラブラになり，指が短くなっ て手袋のようになり，物がつかめなくなるムチラ ンス変形もある。

膝は屈曲拘縮をおこしやすく，曲げておくと膝 痛が少なく，知らないうちに屈曲膝歩行になって しまうので，注意して子防する必要がある。

肘も屈曲拘縮から骨性強直になりやすいし，肩 も挙上出来なくなるので，必ず両方の上肢の運動 を均等に行わなければならない。

趾は第 1 趾が外反し，第 $2-5$ 趾が上を向いて, コックアップトウといわれる変形になってくるの で，予防が大切である。

RA は女性に多く，男性の 4 ～倍といわれて いるが, 初発年齢は, 私の経験でも 1 歳から79歳 に及んでいる。女性は40～50代の発病が多く出産 後の発病や症状の悪化が特徵的である。初発関節

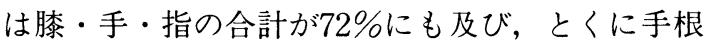
骨附近と中手指関節，近位指関節が侵されやすい ので，他の疾患との鑑別に必ず手と指のX線撮影 をしておく必要がある。中足骨附近も初期に破壊 がみられることが多く，症状がなくても X線撮影 しておくとよい。

RAの自然経過にはいろいろの型があるが，私
の調べた200例の RA で, 関節破壊の進行が遅く， 機能障害があまりひどくならないまま何十年も経 過する型は65\%，2～3 年で急速な関節破壊がお こク，どんな治療にも抵抗する型が $7 \%$ ，徐々に 進行していたのが，10年目前後から急速に悪化し 始める型は $22 \%$ ，初めの $1 \sim 2$ 年一部の関節の破 壊・強直が急速に進行するが, 途中で進行が遅く なり，5１0年後に再び急速に関節症状の悪化す る型は $4 \%$ あるが，この寛解と増悪を繰り返すこ ともある。また，徐々に進行していたのが，進行 が止まり，ごく一部の関節の強直や変形を残して， 全く再発しない型が $2 \%$ 程度あった。これ以外に， 初期や経過中に高熱を出す型， 1 年位の間に RA の診断が確定しないまま治ってしまうものなどい くつかの亜型があるが, 経過中のある時期に急速 な関節の破壊が進むものは，全体の $1 / 3$ 程度あり， 身体障害者になってしまうグループである。 関節破壊について調べてみると ${ }^{2)}$ ，亜脱臼をおこ しやすいのは中手指関節，肘，肩，頸椎で，骨が 癒合する骨性強直は手根骨，足根骨にみられ，変 形性関節症の変化と同様な骨棘などがみられるの はやはり荷重関節である滕，股，腰椎などである。 また，関節がとけてしまういわゆるムチランス型 は，手指，手根骨，肘関節などで，関節の構造や 運動機能，荷重などによって破壊の様相が異って いることがわかる。従って，治療の際運動訓練が 必ずしもよい関節ばかりとは限らず，例えば，手 根骨附近，頸椎の運動は危険で，早めに固めてし まった方がよく，リウマチ体操もやたらにやらせ るべきものではない。

$\mathrm{RA} の$ 機能障害は変形・拘縮以前に，関節及びそ の周囲の疼痛が大きな原因になっている。痛みの 原因として，炎症，拘縮，循環障害，突出部の圧 迫，精神的な因子など多くのものがあり，複雑に 組み合わされているので，例えば関節附近の腱鞘 炎の痛みは関節内に注入したステロイドでは治ら ず，むしろ少量のステロイドを局所に注射するこ とで劇的に治ることがあり，足の裏のたこや魚の 目による痛みは，足底板などで免荷するのがよい。 一般的には疼痛対策として, 基礎的治療の一部で ある炎症関節の固定安静, 保温, さらに物理療法, 薬物療法, 装具の使用, 外科的治療があるが, 内 
科的には薬の使用法が重大なポイントになる。非 ステロイド消炎鎮痛剂の種類は多く，それだけ決 定的なものがない証拠でもあるが，消炎鎮痛効果 の強い薬剤はそれだけ副作用も多いといえる。金 製剂，Dーペニシラミン，免疫抑制剂，免疫調節 郕は頑固な初期の RAの炎症を抑える効果がある が，やはり RA を完全に治療する薬でなく，有効 量と副作用の出る量の幅が狭いので，専門家が注 意して使う必要がある。

消炎鎮痛剂の使用は，医師の好みで選ばれるこ とが多いが，基本的には，血中濃度が長く保たれ るものをべースに使い，数時間程度しか効果のな いものを 1 日のうちの一番工合の悪い時間に重ね て使うとよく, 内服薬は 1 日 3 回食後, 坐薬は就 寝前，ステロイドは朝という原則にこだわらず， 早朝に坐薬を入れるなどの工夫が大切である゙”。副 腎皮質ホルモンはRAの機能障害の予防と治療に は欠かせない薬であるが，出来るだけ少量使用す るよう心掛ける。ステロイドの関節内注入は少く とも 3 週間以上あけ，なるべく効果があって少量 ですむものを使用すると，関節の拘縮予防，機能 訓練にメリットが多いが，技術的な面での難しさ もある゙)。しかし，今だにプレドニリロンを 1 日2 20 〜30mgから漸減して内服させたり，関節注入を毎 週行っている医師も多く，逆に，ステロイドは少 量でも骨関節の破壊をおこすと信じ込んでいる人 がいることも確かである。

RA では胸腰椎の圧迫骨折も多く，とくに中年以 後の女性に多い。第10胸椎から第 2 腰椎の間の骨 折が多いので, 通常の腰椎X線撮影では見逃すお それがある。トイレで立ち上る時などわずかの外 力で骨がつぶれるので，腹筋を鍛えるための体の 前後屈は危険を伴う。一度つぶれた脊椎は $3 \sim 6$ カ月の間に徐々につぶれ続け，次々とその上下の 脊椎がつぶれると亀背になる。通常の圧迫骨折に よく使用されるコルセットはRAの場合すぐに合 わなくなるので実用性はない。疼痛は背中から腹 部へかけて放散するが, 寝かせておくと他の関節 も固まるので, さらしや弾性包帯を巻いて疼痛を 我慢させても起立歩行訓練をさせねばならない。

頸椎は頭の重みで前方に亜脱臼することが多く河, 平均17年経過したRA では，第 $1 ， 2$ 頸椎の覀脱
臼が $68 \%$ ，中下部頸椎は56\%の患者に亜脱臼が認 められた。後屈位でのX線写真ではあまり目立た ない。いずれも，前屈位で覀脱臼が認められるの で，必ず前屈位，左右方向の X 線所見をみておく 必要があると同時に，首を曲げる操作は RA では 禁じておくことが予防につながり，頸椎は早目に カラーで固定する方がよい。

手首に炎症があり，とくに尺骨頭が覀脱臼して いる場合，手首の運動は危険があり，わずかの外 力で第 $5,4,3$ 指の伸筋腱が断裂して伸展が不能 になる。

膝は疼痛が強いと屈曲拘縮になりやすいので, 曲がり始めたらうつぶせにして，アキレス腱の部 分に $1 \mathrm{~kg}$ 位の重錘をかけ，1 日 $2 \sim 3$ 回，30分位 ずつベッド上で伸展させると予防的効果がある。

$1 \sim 2$ 年前から始まった屈曲膝も，関節にひどい 破壊がない場合は，スピードトラックで， $5 \sim 6$ $\mathrm{kg}$ の重錘をかけ，1日2-3 回，30分位ずつ亦引 すると 3 力月から 6 力月で膝が伸びて歩容も改善 される。

肩関節の運動は肩甲骨の動きで代償されるので', 一見動いてみえる肩も，肩甲骨の下縁を押えると 実際は肩関節があまり動いていないことがわかる。 従って，ただ肩を自分で動かすだけの体操はあま り可動域の改善に役立たないことになる。

手指の尺側偏位の予防, 手首の固定, 趾の変形 予防には軽いプラスチック製のスプリント(副子) がよく，日常生活の改善のために柄つきの櫛やス プーンもよく利用される。

以上保存的な RAの管理のごく一部を大ざっぱ に述べてみた。この中で, 疼痛対策の一環として, 疼痛の閾值を上げ，軟部組織の循環を改善，こり をとる目的でRAに使用される鍼炎は，薬物療法 と同様 RAの治療のごく一部に過ぎず，末期のRA に必ずしも適切な手段ではないことを自覚し，気 まぐれで複雑な疾患の経過を変えることより，患 者の日常生活を低下させないための管理の一手段 であることを頭に入れておくことが重要である。

RAの疼痛には精神的な影響も大きく，これを利 用して治療効果をあげることはよいが, 治療する 側が自分の治療法に陶酔して教祖的になり，患者 に正しいRAの管理の仕方を忘れさせるようなこ 
とをしてはならない。

最近，ある疾患に対する漢方薬の二重盲験試験 で，プラセボ(偽薬)の効果が $60 \%$ の患者に認めら れたという事実から，東洋医学に対する日本人の 期待感と精神作用がいかに大きいかがわかると同 時に, 一例報告でなく, 万人が納得出来る客観性 と科学性のある研究態度で臨まれることを，東洋 医学全体に期待して話をしめくくりたいと思う。

\section{参考文献}

1）岡崎 健: 慢性関節リウマチのリハビリテーシ ヨン，日本医事新報 3043;16 20. (1982)

2) 岡崎 健, 前田真治 : 慢性関節リウマチの自然 経過と 5 年間の関節 $\mathrm{X}$ 線所見の変化, 神奈川県 総合リハビリテーションセンター紀要 10;17〜 24. (1983)
3) 岡崎 健：慢性関節リウマチのリハビリテーシ ョンと薬物療法, 総合リハビリテーション 12 ; 121 125. (1984)

4 ) 岡崎 健, 丹沢章八他：慢性関節リウマチのリ ハビリテーションにおける関節管理, 総合リ八 ビリテーション 10;433〜442. (1982)

5 ）岡崎 健：リウマチ体操一頸椎変化を中心に, 総合リハビリテーション 11;105〜110. (1983)

6）岡崎 健：RAの機能障害の保存的療法とその 限界, リウマチ 25;405 408. (1985)

(干141 東京都品川区旗)台1-5-8 昭和大学医学部第一薬理学教室）

\title{
Conservative Treatment of Rheumatoid Arthritis
}

\author{
Ken Okazaki \\ Nanasawa Rehabilitation Hospital
}

According to a newspaper published in 1984, more than $7 \%$ of men and women above 40 years of age living in Ohta-ku were suffering from so-called rheumatic diseases.

Therefore, accurate diagnosis of rheumatoid arthritis (RA), which is only $1 / 10$ of these diseases, is most important when the effect of a certain treatment of RA is estimated. In my opinion, most of the treatments including even new anti-rheumatic drugs do not change the natural course of joint destruction in RA, so we have only procedures of managing RA patients.

Conservative treatment of RA consists of not only effective administration of anti-inflammatory drugs, but also prevention of deformity and contracture of extremities.

Rehabilitation programs to prevent the deformity and contracture were shown in each joint of RA patients.

Although psychological relief of pain may be used effectively in oriental medicine, the fundamental way of managing RA must not be forgotten. 